\title{
A Guideline For Pedagogical Approaches To “Zài(再)”And “Yòu(又)” In Mandarin Chinese For Thai University Students
}

\author{
Sasarux Petcherdchoo, Ph.D., Faculty of Arts, Chulalongkorn University, Thailand
}

\begin{abstract}
The purpose of the study is to provide a guideline for the pedagogical approaches to teach Thai students the grammar of the Chinese adverbs "zài" and "you". Questionnaire results revealed that the reasons for the misuse of "zài" and "yòu" by Thai university students can be classified into three causes: (1) "zài" and "yò" suggest repeatedness and both of them can be literally translated into the Thai $/ I k /,(2)$ the complicated semantic characteristics of "zài" and "yòu" themselves and (3) the situation in the process of "zài" and "yòu" acquisition being not completed. In terms of pedagogical approaches, this study presents an appropriate sequence for the learning of the adverbs "zài" and "yò " in Mandarin Chinese according to the frequency of occurrence and the frequency of error. Furthermore, the study suggests that teachers should first teach the grammar points that are used more frequently and have more straightforward semantics familiar to most students. Those used infrequently and likely to cause errors should be taught later.
\end{abstract}

Keywords: pedagogical approaches, adverbs, Mandarin Chinese, grammar

\section{INTRODUCTION}

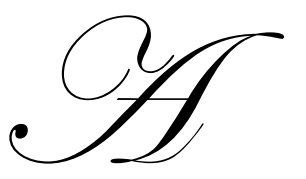

ccording to the Modern Standard Beijing Chinese Frequency Dictionary, the adverbs “zài( 再)" and "yòu (又)" in Mandarin Chinese are used so frequently that they should be emphasized in the elementary stages of learning. However, current teaching materials do not provide any clarification of the meaning of these two adverbs. In the elementary learning of Thai students, these two adverbs both express the recurrence of an action or a state and Thai students always compare these two adverbs with the Thai word /Ik/ because the word /Ik/can be used in a situation where an action or state either has not occurred or has already occurred. Thus, in teaching Thai students approaches to "zài" and "yòu" it must be stressed that "zài" suggests an action that has not yet happened whereas "yòu" suggests an action by a more determined speaker or an action that has already happened. In any case, according to Pensuda Chowvanich's statistics in her Master's degree thesis Common errors in the use of the Chinese language by Chulalongkorn University Arts students in the academic years 2000 and 2001, it is suggested that Thai students' secondary mistake in their Chinese syntactic structure is the misuse of adverbs. In this study, Pensuda concludes that it is the adverbial "yòu" that is largely misused in these circumstances. She indicates that Thai students often treat both of these adverbs in their translations like the Thai /lk/, which has a double correspondence with the two adverbs. Furthermore, "zài" and "yòu" also have complicated semantic characteristics and do not only refer to "repeatedly". Thus, each of their semantic characteristics should attract an appropriate pedagogical approach. However, in cases where items share the same structure but are distinct semantically, it is important to understand how to introduce all the properties in a meaningful way and encourage learning in an effective fashion and sequence. The important point is how is the sequence determined? And decision may have to be more than just a matter of arbitrariness or common sense. 


\section{Objectives}

The main objective of the study is to suggest a guideline for the pedagogical approaches to teach Thai students the grammar of the Chinese adverbs "zài" and "yòu".

\section{Theoretically background}

Pattern sequencing is one autonomous pedagogical grammar theory that is based on the difficulty of the sentence pattern and the frequency of occurrence to produce a teaching sequence (Teng,1998). Hence, in this paper, the pedagogical approaches of the Chinese adverbs "zài" and "yòu" can be primarily suggested according to the frequency of occurrence and the frequency of errors.

\section{Method of the study}

First, 500 illustrative sentences have been selected randomly for each of the adverbs "zài" and "yòu", picked from the corpus of Beijing University's Chinese Linguistics Research Centre and the corpus of NCIKU', and then analyzed them in term of grammatical structure and semantic meaning, correspondingly, simple statistics (percentages) were applied as a guideline for the pedagogical approach.

Then, a questionnaire on the use of "zài" and "yòu" was conducted with 100 Thai university students majoring in Chinese from three representative universities with the purpose of understanding the mistakes of Thai students when using "zài" and "yòu". Afterwards, the students" responses were sequenced from the least to the most according to their frequency of errors.

\section{Conventions}

The examples of Chinese sentences use Chinese Pinyin Romanization and those of the Thai words use the Thai Romanization of the Department of Linguistics at Chulalongkorn University to facilitate pronunciation.

\section{LITERATURE REVIEW}

\section{Semantic meaning of "zài" and "yòu"}

In Chinese linguistic research, "zài" and "yòu" differ in terms of part of speech and analysis of meaning and usage; however, regularly, teaching materials treat both of them as adverbial and widely treat these two adverbs as recurrent actions or states that are differentiated by being "undone/unaccomplished" or "done/accomplished". Based on previous results from research on "zài" and "yòu", we can summarize the semantic meaning of "zài" and "yòu" as seen below.

Table 2.1

\begin{tabular}{|c|c|c|c|}
\hline \multicolumn{4}{|c|}{ Semantic meaning of "zài" and "yòu" } \\
\hline & 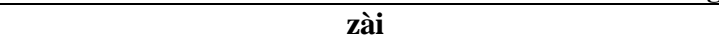 & & yòu \\
\hline 1 & $\begin{array}{l}\text { Refers to an action (an event) taking place repeatedly or } \\
\text { continually. }\end{array}$ & 1 & Refers to an action (an event) taking place repeatedly. \\
\hline 2 & Refers to something that happens after an action. & 2 & $\begin{array}{l}\text { Refers to several accumulated actions, situations and } \\
\text { circumstances. }\end{array}$ \\
\hline 3 & Refers to an increased degree or a wider extent. & 3 & Refers to certain moods. \\
\hline 4 & Refers to "furthermore". & 4 & Refers to "addition". \\
\hline
\end{tabular}

\footnotetext{
${ }^{1}$ http://ccl.pku.edu.cn. and www.nciku.com.

2 Zhào Yuánrèn( 1968 : $387-390,143$ - 144 ), Lü Shūxiāng (1999 : 633 - 635 , 642 - 644 ), Liú Yuèhuá (2001:235-238, 238-242) and Lú Fúbō (2003:605-607)
} 
In table 2.1 "zài 1" and "yòu 1" all refer to repeated actions, however Lú Fúbō (2003:605-607) indicates that "zài" and "yòu" refer to repeated or continued actions but are interpreted in different ways. When expressing an act that is repeatedly occurring or continuous, "zài” expresses subjectivity. It is used to describe the speaker's desire or plan to repeat or continue some action himself or the speaker's demand that the listener repeat or continue some action. It is usually used to express something unfinished. When expressing an act that is repeatedly occurring or continuous, "yòu" expresses objectivity. It is used when the speaker states that the action or state of himself or others has been or will be repeated or continued. It is usually used to express something finished or something new emerging.

\section{A comparison of the adverbs "zài" and "yòu" with Thai}

Based on Paisarn Sukjairungwattana's statistics in his Master's degree thesis, A comparative Study of adverbs "zài" and "yòu" in Mandarin Chinese and / i:k $\beta$ in Thai, a comparison of the adverbs "zài" and "yòu" with Thai can be shown as below.

"zài/yòu" can suggest a repeated action or condition. As for recurrence, "zài/yòu" and the Thai /Ik/have the same basic function. This is because the basic function of the Thai /Ik/ also suggests a repeated action or condition. Also, the difference between "zài" and "yòu" is that "zài" suggests an action that has not yet happened, whereas "yòu" suggests an action by a more determined speaker or an action that has already happened. Different temporal distinctions are made in "zài" and "yòu": "zài" is related to the future but "yòu" is related to the past and the present. However, the Thai word $/ \mathrm{Ik} /$ does not seem to have any temporal distinction and simply suggests the recurrence of an action/condition. This is because the Thai word / Ik/ does not suggest an action that is done or undone but, if one wants to suggest an action that is done, the Thai adverb /laeo/ (แล้) can be added to suggest the past tense. / Ik / in Thai relies to the context in order to make a distinction between the present and the future. Thus, the temporal question of / Ik / in Thai is different from the self-reliance of "zài/yòu".

Without any temporal condition, the Thai /Ik/can be used in the past and the future. It is unlike "zài" and "yòu". "zài" proposes a warning against undone things without any discontent but "yòu" suggests discontent at a repeated thing in the past. However, while expressing the same mood, the Thai /Ik/ is not restrained by such temporal rules.

From the aspect of mood, "zài" and "yòu" can suggest several moods: "zài" is used to express discontent, a reproach of others or the preventing of others from doing something; and, "yòu" is used to express discontent, the reproach of others, rationalization or debate. "zài" is used to supply an "imperative" mood. It is an imperative mood where one cannot ask for reasons. This category of "zài" also can be translated into /Ik/. "Yòu" is used to achieve an unsatisfying mood. It is the type of mood where one can ask for reasons. This category of "yòu" is so mood-conditioned that any translation must be done according to the context.

"zài" in the "zài+adjective" formation suggests increased degree and resembles the Thai word /Ik because that Thai /Ik/ can be used to suggest increased degree.

When "zài” suggests one thing happening after another it should be translated as the Thai adverb /khoi/ (ค่อย), not $/ \mathrm{Ik} /$.

When "yòu” suggests a complement it should be translated into the Thai adverbial /thang/(ทั้ง), not /Ik/.

When "zài" and "yòu" match with Nominal/ Verbal measure words they can be translated into /Ik/. Yet, in "Yi $(-)+$ Nominal measure word + yòu + yi $(-)+$ Nominal/ Verbal measure word" formation, "yòu" has to be translated into the Thai conjunction /...laeo ... lao/(...แล้ว... เล่า).

According to the above most categories of "zài" and "yòu" can be translated into the Thai/Ik/. It is a positive transfer but it can easily be a negative transfer too.

\footnotetext{
${ }^{3}$ This paper will use the Thai Romanization /Ik/ instead of the International Phonetics Alphabet /i:k/.
} 


\section{THE FREQUENCY OF OCCURRENCE}

We randomly collected 500 illustrative sentences for each of "zài" and "yòu", picked from the corpus and analyzed their grammatical structure together with their function and usage.

"zài"

We analyzed 500 illustrative sentences of "zài" and the results are shown in table3.1 below:

Table 3.1 Grammatical structure, function and use of "zài"

\begin{tabular}{|c|c|c|c|}
\hline \multicolumn{4}{|c|}{ "zài"” } \\
\hline \multirow[b]{2}{*}{$\begin{array}{l}\text { Grammatical } \\
\text { structure }\end{array}$} & \multirow[b]{2}{*}{ Function } & \multirow[b]{2}{*}{ Usage } & Category \\
\hline & & & $\begin{array}{l}\text { The frequency of } \\
\text { occurrence/total } \\
\text { (percentage) }\end{array}$ \\
\hline \multirow[t]{6}{*}{ 1. "zài + verb" } & \multirow{4}{*}{$\begin{array}{l}\text { Use before a verb to } \\
\text { express the recurrence of } \\
\text { an action or situation. }\end{array}$} & $\begin{array}{l}\text { 1. To indicate that the same action or situation will } \\
\text { occur again. }\end{array}$ & $\begin{array}{l}\text { "zài1(a1)" } \\
56 / 500(11.2)\end{array}$ \\
\hline & & $\begin{array}{l}\text { 2. To indicate that the same action or situation } \\
\text { occurs continually. }\end{array}$ & $\begin{array}{l}\text { "zài1(a2)" } \\
42 \text { / } 500(8.4)\end{array}$ \\
\hline & & $\begin{array}{l}\text { 3. To indicate that the same action or situation will } \\
\text { occur again in conditional or suppositional clauses }\end{array}$ & $\begin{array}{l}\text { "zài1(a3)" } \\
93 \text { / } 500 \text { (18.6) }\end{array}$ \\
\hline & & $\begin{array}{l}\text { 4. To indicate that the same action or situation will } \\
\text { occur again and add more quantity, after the "zài } \\
\text { +verb" formation have a measure word. }\end{array}$ & $\begin{array}{l}\text { "zài1(a4)" } \\
48 \text { / } 500 \text { (9.6) }\end{array}$ \\
\hline & $\begin{array}{l}\text { Use before a verb to } \\
\text { express a sequencing of a } \\
\text { situation. }\end{array}$ & $\begin{array}{l}\text { To indicate that an action starts after another action } \\
\text { has finished, always preceded by an expression of } \\
\text { time or condition. }\end{array}$ & $\begin{array}{l}\text { "zài1(b)" } \\
138 \text { / } 500 \text { (27.6) }\end{array}$ \\
\hline & $\begin{array}{l}\text { Use before a verb to } \\
\text { express the addition of an } \\
\text { action or situation; on top } \\
\text { of that }\end{array}$ & $\begin{array}{l}\text { To indicate that a different action or situation will } \\
\text { occur in addition or to indicate additional } \\
\text { information. }\end{array}$ & $\begin{array}{l}\text { "zài1(c)" } \\
27 \text { / } 500 \text { (5.4) }\end{array}$ \\
\hline \multicolumn{3}{|l|}{ Total } & $404 / 500(80.8)$ \\
\hline \multirow[t]{2}{*}{$\begin{array}{c}\text { 2. "zài+ } \\
\text { adjective" }\end{array}$} & \multirow{2}{*}{$\begin{array}{l}\text { Use before an adjective to } \\
\text { express increasing in } \\
\text { degree }\end{array}$} & 1.To indicate a greater degree & $\begin{array}{l}\text { "zài2(a)" } \\
17 \text { / } 500(3.4)\end{array}$ \\
\hline & & $\begin{array}{l}\text { 2. To indicate a greater degree in conditional or } \\
\text { suppositional clauses. }\end{array}$ & $\begin{array}{l}\text { "zài2(b)" } \\
49 \text { / } 500 \text { (9.8) }\end{array}$ \\
\hline \multicolumn{3}{|l|}{ Total } & $86 / 500(13.2)$ \\
\hline $\begin{array}{l}\text { 3. "zài + measure } \\
\text { word" }\end{array}$ & $\begin{array}{l}\text { Use before a measure } \\
\text { word to express } \\
\text { "another". }\end{array}$ & To indicate another one. & $\begin{array}{l}\text { "zài3" } \\
30 \text { / } 500 \text { (6) }\end{array}$ \\
\hline \multicolumn{3}{|l|}{ Total } & $30 / 500(6)$ \\
\hline
\end{tabular}

Table3.1 shows the grammatical structure, function and use of the adverb "zài". The information in the table can be summarized as follows:

1. There are three main grammatical structures of "zài": (1) "zài + verb" (accounting for 80.8\%), (2) "zài + adjective" (accounting for 13.2\%) and (3) "zài + measure word" (accounting for 6\%).

2. "zài" in the "zài + verb" formation, also called "zàil", has three main functions:

(1) "zài1 (a)" is used before a verb to express the recurrence of an action or situation. As for usage, "zài1

(a)" can be categorized into four types:

"zài1 (a1)" (accounting for 11.2\%) is used to indicate that the same action or situation will occur again. For example:

(1) 我再说明一下, 免得引起误会。

Wǒ zài shuōmíng yíxià, miănde yǐnqǐ wùhuì.

To avoid any misunderstanding, let me explain again.

(2) 把木棍再削一削。

Bă mùgùn zài xiāo yi xiāo.

Whittle the stick down again. 
"zài1 (a2)" (accounting for 8.4\%) is used to indicate that the same action or situation occurs continually. For example:

(3) 别再保密了, 你的话已经露馅儿了。

Bié zài băomì le, nǐ de huà y̌̌jīng lòuxiànr le.

Don't try to keep it a secret any longer. Yòu've already given the game away.

(4) 快走吧, 别再磨时间了。

Kuài zǒu ba, bié zài mó shíjiān le.

Don't dawdle anymore and get going.

"zài1 (a3)" (accounting for 18.6\%) is used to indicate that the same action or situation will occur again in conditional or suppositional clauses. For example:

（5）我再卖力气也不容易讨她的好。

Wǒ zài mài lìqi yě bù róngyì tăo tā de hăo.

She is hard to please no matter how much harder I try.

(6) 你再那么做, 我可要恼了。

Nǐ zài nàme zuò, wǒ kě yào năo le.

If you do that again, I'll get angry.

"zài1(a4)" (accounting for 9.6\%) is used to indicate that the same action or situation will occur again and add more quantity, after the "zài +verb" formation there will always be a measure word. For example:

(7) 把桌子再漆一遍。

Bă zhuōzi zài qī yí biàn.

Give the table another coat of paint.

(8) 行李卷儿外边再裹一层塑料布。

Xínglǐjuănr wàibian zài guǒ yì céng sùliào bù.

Wrap another plastic sheet around the bedroll.

(2) "zài1 (b)" (accounting for 27.6\%) is used before a verb to express the sequencing of a situation to indicate that an action starts after another action finishes and is always preceded by an expression of time or condition. For example:

(9) 吃了饭再走吧!

Chīle fàn zài zǒu ba!

Please go after finishing dinner.

(10) 水太浑啦, 沉淀一下再用。

Shuǐ tài hún la, chéndiàn yí xià zài yòng.

The water is too muddy and can be used after it has been allowed to settle for a while.

(3) "zài1(c)" (accounting for 5.4\%) is used before a verb to express the addition of an action or situation and, on top of that, to indicate the additional information. For example:

(11) 到会的有教职员工，再就是学生代表。

Dào huì de yǒu jiàozhíyuángōng, zài jiùshì xuéshēng dàibiăo.

Present at the meeting were teachers, administrative personnel and workers, and also representatives of the students.

\section{(12) 现在去找他太晚了，再说我路也不熟。}

Xiànzài qù zhăo tā tài wăn le, zài shuō wǒ lù yě bù shú.)

It's too late to go and see him now; besides, I don't really know the way.

3. "zài" in the "zài + adjective" formation, also called "zài2", is used before an adjective to express increase in degree. As for usage, "zài2" can be categorized into two types:

(1) “zài2 (a)" (accounting for 3.4\%) is used to indicate greater degree. For example:

(13) 坑边挖得太陡了, 再坡一点。

Kēng biān wā de tài dǒu le, zài pō yìdiăn.

The sides of the pit are too steep. Slope them a bit more.

(14) 声音再大一点。

Shēngyìn zài dà yì diăn.

Still louder, please. 
For example:

(2) "zài2 (b)" (accounting for 9.8\%) is used to indicate greater degree in conditional or suppositional clauses.

(15) 快走吧, 再晚就什么也吃不上了。

Kuài zǒu ba, zài wăn jiù shénme yě chī bu shàng le.

Hurry up or we'll be too late to get anything to eat.

(16) 哪怕困难再大，我们也能克服。

Năpà kùnnan zài dà, wǒmen yě néng kèfú.

However great the difficulties may be, we can overcome them.

4. "zài" in the "zài + measure word" formation, also called "zài3" (accounting for 6\%), is used before an adjective to express "another", to indicate the another one. For example:

(17) 我期待着在西安再一次和你相会。

Wǒ qīdàizhe zài Xī'ān zài yí cì hé nǐ xiānghuì.

I'm looking forward to meeting you another time in Xi'an.

(18) 再一个夜班, 我也完全吃得消。

Zài yí gè yèbān, wǒ yě wánquán chīdexiāo.

I can easily stand working another night shift.

"yòu"

We analyzed 500 illustrative sentences of "yòu" and the results are as in table3.2 below:

Table 3.2 Grammatical structure, function and usage of "yòu"

\begin{tabular}{|c|c|c|c|}
\hline \multicolumn{4}{|c|}{ yòu } \\
\hline Grammatical & \multirow[b]{2}{*}{ Function } & \multirow[b]{2}{*}{ Usage } & Category \\
\hline structure & & & $\begin{array}{l}\text { The frequency of } \\
\text { use/total(percentage) }\end{array}$ \\
\hline \multirow[t]{5}{*}{ 1. "yòu + verb" } & \multirow{2}{*}{$\begin{array}{l}\text { Use before a verb to } \\
\text { express the recurrence of } \\
\text { an action or situation. }\end{array}$} & $\begin{array}{l}\text { 1. To indicate the same action has already occurred } \\
\text { again. }\end{array}$ & $\begin{array}{c}\text { "yòu 1 (a1)" } \\
237 / 500(47.4) \\
\end{array}$ \\
\hline & & $\begin{array}{l}\text { 2. To indicate the same action or situation has occurred } \\
\text { again and add more quantity, after the "yòu + verb" } \\
\text { formation having a measure word. }\end{array}$ & $\begin{array}{l}\text { "yòu 1 } 1 \text { (a2)" } \\
\text { 42/ 500(8.4) }\end{array}$ \\
\hline & \multirow[t]{2}{*}{$\begin{array}{l}\text { Use before a verb to } \\
\text { express "addition" of the } \\
\text { event; on top of that }\end{array}$} & $\begin{array}{l}\text { 1. To indicate the simultaneous existence of several } \\
\text { actions or situations, sometimes using "yòu" } \\
\text { reduplicated or in the "ji (既)..., yòu.." formation. }\end{array}$ & $\begin{array}{l}\text { "yòu } 1(\mathrm{~b} 1) " \\
73 / 500(14.6)\end{array}$ \\
\hline & & $\begin{array}{l}\text { 2. Not only to indicate different actions or situations } \\
\text { occurring in addition but also the actions or situations } \\
\text { being contrary actions or ideas. }\end{array}$ & $\begin{array}{l}\text { "yòu } 1(\mathrm{~b} 2) " \\
51 / 500(10.3)\end{array}$ \\
\hline & $\begin{array}{l}\text { Use before a verb to } \\
\text { express a certain mood. }\end{array}$ & $\begin{array}{l}\text { Not to emphasize the same action or situation has } \\
\text { occurred but to refer to a certain mood, always used in } \\
\text { a negative statement or a rhetorical question for } \\
\text { emphasis. }\end{array}$ & $\begin{array}{l}\text { "yòu 1(c)" } \\
21 / 500(4.3)\end{array}$ \\
\hline \multicolumn{3}{|r|}{ ( } & 424 / $500(84.8)$ \\
\hline \multirow[t]{2}{*}{$\begin{array}{l}\text { 2. "yòu }+ \\
\text { adjective" }\end{array}$} & $\begin{array}{l}\text { Use before an adjective } \\
\text { to express the recurrence } \\
\text { of a state. }\end{array}$ & To indicate the same state has already occurred again. & $\begin{array}{l}\text { “yòu } 2 \text { (a)" } \\
4 \text { / 500(0.8) }\end{array}$ \\
\hline & $\begin{array}{l}\text { Use before an adjective } \\
\text { to express "addition" }\end{array}$ & $\begin{array}{l}\text { To indicate the simultaneous existence of several } \\
\text { states, "yòu" is always reduplicated or in the "ji (既).., } \\
\text { yòu..." formation. }\end{array}$ & $\begin{array}{l}\text { "yòu 2(b)" } \\
31 / 500(6.2)\end{array}$ \\
\hline \multicolumn{3}{|r|}{ S } & $35 / 500(7)$ \\
\hline \multirow[t]{2}{*}{$\begin{array}{c}\text { 3. "yòu }+ \\
\text { measure word" }\end{array}$} & $\begin{array}{l}\text { Use before a measure } \\
\text { word to refer to } \\
\text { "another". }\end{array}$ & To indicate another one has already occurred. & $\begin{array}{c}\text { "yòu } 3 \text { (a)" } \\
38 \text { / 500(7.6) }\end{array}$ \\
\hline & $\begin{array}{l}\text { Use before a measure } \\
\text { word to refer to } \\
\text { "addition". }\end{array}$ & To indicate a whole number and a fraction & $\begin{array}{l}\text { "yòu } 3(b) " \\
3 / 500(0.6)\end{array}$ \\
\hline \multicolumn{3}{|l|}{ Total } & $41 / 500(8.2)$ \\
\hline
\end{tabular}


Table3.2 shows the grammatical structure, function and usage of the adverb "yòu". The information in the table can be summarized as follows:

1. There are three main grammatical structures of "yòu": (1) "yòu + verb" (accounting for 84.8\%), (2) "yòu + adjective" (accounting for 7\%) and (3) "yòu + measure word" (accounting for 8.2\%).

2. "yòu" in the "yòu + verb" formation, also called "yòu 1", has three main functions:

(1) "yòu 1(a)" is used before a verb to express the recurrence of an action or situation. As for usage, "yòu 1(a)" can be categorized into two types:

"yòu 1(a1)" (accounting for 47.4\%) is used to indicate the same action has already occurred again. For example:

(1) 你看, 又把房门钥匙锁在屋子里了。

Nĩ kàn, yòu bă fángmén yàoshi suǒ zài wūzi li le.

Look, he's locked his key inside his room again.

（2）孩子们把这首诗念了又念，现在都能琅琅上口了。

Háizimen bă zhè shǒu shī niànle yòu niàn, xiànzài dōu néng lánglángshàngkǒu le.

The children have read the poem several times and can all recite it quite fluently now.

"yòu 1(a2)" (accounting for 8.4\%) is used to indicate the same action or situation has occurred again and adds more quantity, after the "yòu +verb" formation having a measure word. For example:

(3) 他们一计不成, 又生一计。

Tāmen yí jì bù chéng, yòu shēng yí jì.

Their first ruse having failed, they tried another.

（4）中国队又夺得四枚金牌，跻身世界四强。

Zhōngguóduì yòu duódé sì méi jīnpái, jīshēn shìjiè sì qiáng.

The Chinese team captured another four gold medals which put them in the ranks of the top four.

(2) "yòu 1(b)" is used before a verb to express the "addition" of an action or situation; on top of that. As for usage, "yòu 1(b)" can be categorized into two types:

"yòu 1(b1)" (accounting for 14.6\%) is used to indicate the simultaneous existence of several actions or situations, sometimes using “yòu” reduplicated or in the "ji (既).., yòu.." formation. For example:

(5) 这件事还没处理完，那件事又蹦出来了。

Zhè jiàn shì háiméi chǔlǐ wán, nà jiàn shì yòu bèng chūlái le.

One problem had scarcely been solved when another cropped up.

(6) 既要有远大的理想, 又要脚踏实地地干。

Jì yào yǒu yuăndà de lǐxiăng, yòu yào jiăotàshídì de gàn.

Have both an ambitious goal and a down-to-earth style of work.

"yòu 1(b2)" (accounting for 10.3\%) not only indicates a different action or situation occurring in addition but also that the action or situation is a contrary action or idea. For example:

（7）答应吧，办不到; 不答应吧，又有点难为情。

Dāyìng ba, bàn bu dào; bù dāyìng ba, yòu yǒudiăn nánwèiqíng.

It is not feasible to comply but it is a bit embarrassing to refuse.

（8）我想问他借钱，但又觉得难以启齿。

Wǒ xiăng wèn tā jièqián, dàn yòu juéde nány̌̌qǐchǐ.

I wanted to borrow money from him but found it difficult to bring the matter up.

(3) "yòu 1(c)" (accounting for 4.3\%) is used before a verb to express a certain mood. As for its usage, it is not to emphasize that the action or situation has occurred but it always refers to discontent and is used in a negative statement or a rhetorical question for emphasis. For example:

(9) 别客气, 我又不是外人。

Bié kèqi, wǒ yòu bú shì wàirén.

Don't stand on ceremony. I'm no stranger! 
(10) 这个坏家伙又在搞什么名堂?

Zhè ge huài jiāhuo yòu zài găo shénme míngtang?

What's that villain up to now?

3. "yòu", in the "yòu + adjective" formation , also called "yòu 2", has two main functions: example:

(1) "yòu 2(a)" (accounting for $0.8 \%$ ) is used to indicate the same state has already occurred again. For

(11) 声音又大起来了。

Shēngyīn yòu dà qǔlái le.

Louder again.

(12) 那位姑娘脸又红了。

Nà wèi gūniang de liăn yòu hóng le.

That young lady is shameless again.

(2) "yòu 2(b)" (accounting for 6.2\%) to indicate the simultaneous existence of several states, "yòu" always being reduplicated or in the "ji (既).., yòu..” formation. For example:

(13) 这间屋子既宽敞, 又亮堂。

Zhè jiān wūzi jì kuānchang, yòu liàngtang.

The room is both light and spacious.

(14) 她们纺的线又细又匀。

Tāmen făng de xiàn yòu xì yòu yún.

The thread they spin is thin and smooth.

4. "yòu" in the "yòu + measure word" formation, also called "yòu 3", has two main types:

(1) "yòu 3(a)" (accounting for 7.6\%) is used before a measure word to refer to "another", to indicate another one has already occurred. For example:

(15) 又一艘新船下水了。

Yòu yì sōu xīn chuán xià shuĩ le.

Another new ship was launched.

(16) 如何使市场经济有序运行成了又一课题。

Rúhé shǐ shìchăng jīngjî yǒuxù yùnxíng chéngle yòu yí kètí.

How to run an orderly market economy became another problem.

(2) "yòu 3(b)" (accounting for $0.6 \%$ ) is used before a measure word to refer to "addition", to indicate a whole number and a fraction. For example:

(17) 一圣三分之二

Yí yòu sānfēnzhī'èr

One and two thirds

(18) 一个月㕛三天

Yí ge yuè yòu sān tiān

One month and three days

In table 3.1 and 3.2, the frequency of 500 illustrative sentences of each "zài" and "yòu" in the corpus can be sequenced from the most to the fewest as follows: 
Table 3.3 the occurring sequence of "zài" and "yòu"

\begin{tabular}{|c|c|c|c|c|c|}
\hline \multicolumn{6}{|c|}{ The occurring sequence of "zài" and "yòu" } \\
\hline "zài" category & $\begin{array}{c}\text { Frequency of } \\
\text { occurrence } \\
\text { (percentage) }\end{array}$ & sequencing & "yòu" category & $\begin{array}{c}\text { Frequency of } \\
\text { occurence } \\
\text { (percentage) }\end{array}$ & sequencing \\
\hline "zài1(a1)" & $11.2 \%$ & 3 & "yòu 1 (a1)" & $47.4 \%$ & 1 \\
\hline "zài1(a2)" & $8.4 \%$ & 6 & "yòu 1 (a2)" & $8.4 \%$ & 4 \\
\hline "zài1(a3)" & $18.6 \%$ & 2 & "yòu 1 (b1)" & $14.6 \%$ & 2 \\
\hline "zài1(a4)" & $9.6 \%$ & 5 & "yòu 1 (b2)" & $10.3 \%$ & 3 \\
\hline "zài1(b)" & $27.6 \%$ & 1 & "yòu 1 (c)" & $4.3 \%$ & 8 \\
\hline "zài1(c)" & $5.4 \%$ & 8 & "yòu 2 (a)" & $0.8 \%$ & 7 \\
\hline "zài2(a)" & $3.4 \%$ & 9 & "yòu 2 (b)" & $6.2 \%$ & 6 \\
\hline "zài2(b)" & $9.8 \%$ & 4 & "yòu 3 (a)" & $7.6 \%$ & 5 \\
\hline “zài3” & $6 \%$ & 7 & "yòu 3 (b)" & $0.6 \%$ & 9 \\
\hline
\end{tabular}

\section{THE FREQUENCY OF ERRORS}

In the previous chapter, we collected illustrative sentences to analyze the grammatical structure, functions and usage of the adverbs "zài" and "yòu" and also established the sequence of the frequency of occurrence. In this chapter we will describe how we conducted an experimental study with Thai university students on the use of the adverbial "zài" and "yòu" in order to understand the problems they have when using these adverbs. The result of the test is referred to to suggest a pedagogical grammar for the adverbs "zài" and "yòu" for Thai university students.

Representative samples were selected from a random sampling of 100 Thai university students who were Chinese language majors from three universities. This experimental sample took no account of the sex or age of the samples. The experimental samples were divided into two groups:

(1) Group A, 50 students who had already studied about 480 hours of Chinese.

(2) Group B, 50 students who had already studied about 780 hours of Chinese.

The experimental instrument was a questionnaire which asked the Thai University students randomly about the use of "zài" and "yòu" with respect to their semantic meaning in certain situations. The questionnaire had two sections: section one provided information about the participants' backgrounds, for example, learning experience and their knowledge of "zài" and "yòu" grammar; section two consisted of 36 sentences in which students had to select "zài" and "you" to fill in the blanks. These 36 sentences presented 9 categories each of "zài" and "yòu" to test the participant's knowledge of "zài" and "yòu" simply.

\section{Experimental results}

From the experimental results, the frequency of error of each "zài" and "yòu" can be sequenced from fewest to the most as follows:

Table 4.1 the frequency of error of each "zài" and "yòu"

\begin{tabular}{|c|c|c|c|c|c|}
\hline \multicolumn{2}{|c|}{ zài } & \multicolumn{3}{c|}{ yòu } \\
\hline Category & $\begin{array}{c}\text { Frequency of } \\
\text { error / total }\end{array}$ & sequencing & Category & $\begin{array}{c}\text { Frequency of } \\
\text { error / total }\end{array}$ & sequencing \\
\hline "zài1(a1)" & $14 / 200$ & 1 & "yòu 1 (a1)" & $48 / 200$ & 3 \\
\hline "zài1(a2)" & $18 / 200$ & 2 & "yòu 1 (a2)" & $43 / 200$ & 2 \\
\hline "zài1(a3)" & $104 / 200$ & 7 & "yòu 1 (b1)" & $63 / 200$ & 6 \\
\hline "zài1(a4)" & $80 / 200$ & 6 & "yòu 1 (b2)" & $49 / 200$ & 4 \\
\hline "zài1(b)" & $36 / 200$ & 5 & "yòu 1 (c)" & $62 / 200$ & 5 \\
\hline "zài1(c)" & $110 / 200$ & 8 & "yòu 2 (a)" & $70 / 200$ & 7 \\
\hline "zài2(a)" & $30 / 200$ & 4 & "yòu 2 (b)" & $32 / 200$ & 1 \\
\hline "zài2(b)" & $139 / 200$ & 9 & "yòu 3 (a)" & $120 / 200$ & \\
\hline "zài3" & $29 / 200$ & 3 & "yòu 3 (b)" & $184 / 200$ & \\
\hline Total & $\mathbf{5 6 0 / 1 8 0 0}$ & - & Total & $\mathbf{6 4 9 / 1 8 0 0}$ & 9 \\
\hline
\end{tabular}


In table 4.1, "zài" has 560 error sentences from 1,800 sentences; "yòu" has 649 error sentences from 1,800 sentences.

According to the results from the first part of the questionnaire, we found that most of the participants (73 students) knew that "zài" suggests an action that has not yet happened but "yòu" suggests an action by a more determined speaker or an action that has already happened and is comparable with the Thai /Ik/. When using these two adverbs they always feel confused. Few students (5 students) knew that these two adverbs are not only used to indicate recurrence but also have another meaning. All of them knew that in some formations, such as in the "xian

( 先 )... zài" formation, it is suggested that one thing happens after another and can be translated as the Thai adverb /khoi/(ค่อย), not /Ik/; “yòu” reduplicated or in the "ji (既).., yòu.." formation is used to indicate the simultaneous existence of several actions or situations, etc.

The results from the second part of the questionnaire were analyzed together with the first part. We found three main reasons for errors:

(1) There is the error caused by first language transfer in the learning process which is called negative transfer. The correct usage rate of students is low when "zài" and "yòu" correspond in Thai and Chinese and this means that when students learn that "zài" and "yòu" can be literally translated into the Thai /Ik/, the Thai/lk/ is not equivalent to all categories of "zài" and "yòu and then a negative transfer occurs.

(2) The complex semantic functions and multiple usages of "zài" and "yòu" themselves. "zài" and "yòu" have at least three different semantic functions and some functions have many multiple usages. Thus, it can be said that "zài" and "yòu" have many categories and their semantic functions and multiple usages are so complex that if cumulative learning is not entirely planned, student acquisition will contain errors too.

(3) The situation in the process of "zài" and "yòu" acquisition is not complete. Most students do not know that these two adverbs can be used to suggest recurrence and can be used in some formations with another meaning. They do not know the other semantic functions and other usages of "zài" and "yòu", such as the 120 error sentences of "yòu 3 (a)", the 184 error sentences of "yòu 3 (b)", if these two categories of "you" had been taught before maybe fewer errors would occur. However the frequency of occurrence for these two categories of "yòu" is lower than for others, so maybe they should be taught at the last stage of the pedagogical grammar of "yòu" even though the frequency of error is very high.

\section{PEDAGOGICAL GRAMMAR OF "zài” AND "yòu”}

Teng (2006) states that pedagogical grammar is cumulative and entails the following: Grammar points within each stage are sequenced; Sequencing can be defined on the basis of complexity, frequency of occurrence, inter-language distance and L1/L2 acquisition factors. Pedagogical grammar is sequential, such as A precedes B if A has a higher frequency count or if $\mathrm{A}$ is structurally and semantically less complex or if $\mathrm{A}$ has a lesser inter-language distance etc.

In the previous chapters, the study discusses the frequency of occurrence and the frequency of errors of "zài" and "yòu". From the above statistical results, the frequency of occurrence can be sequenced from most to least and those that usually occur should be taught first. But the frequency of errors can be sequenced from least to most so the fewer errors are less difficult so this should be taught first.

Table 5.1: The statistical sequence of "zài"

\begin{tabular}{|c|c|c|c|c|c|c|c|c|c|}
\hline Category & $\begin{array}{l}\text { zài1 } \\
\text { (a1) }\end{array}$ & $\begin{array}{l}\text { zài1 } \\
\text { (a2) }\end{array}$ & $\begin{array}{l}\text { zài1 } \\
\text { (a3) }\end{array}$ & $\begin{array}{l}\text { zài1 } \\
\text { (a4) }\end{array}$ & $\begin{array}{c}\text { zài1 } \\
\text { (b) }\end{array}$ & $\begin{array}{c}\text { zài1 } \\
\text { (c) }\end{array}$ & $\begin{array}{l}\text { zài2 } \\
\text { (a) }\end{array}$ & $\begin{array}{c}\text { zài2 } \\
\text { (b) }\end{array}$ & zài3 \\
\hline The frequency of errors & 1 & 2 & 7 & 6 & 5 & 8 & 4 & 9 & 3 \\
\hline The frequency of occurrence & 3 & 6 & 2 & 5 & 1 & 8 & 9 & 4 & 7 \\
\hline Accumulated score & 4 & 8 & 9 & 11 & 6 & 16 & 13 & 13 & 10 \\
\hline Intra-sequencing & 1 & 3 & 4 & 6 & 2 & 8 & 7 & 7 & 5 \\
\hline
\end{tabular}


In table 5.1, the statistical sequence of "zài" is sequenced as follows:

1. zài1 (a1)

2. $\quad$ zài1 (b)

3. zài1 (a2)

4. zài1 (a3)

5. zài3

6. zài1 (a4)

7. zài2 (a) and zài2 (b)

8. zài1(c)

Table 5.2: The statistical sequence of "yòu"

\begin{tabular}{|c|c|c|c|c|c|c|c|c|c|}
\hline Category & $\begin{array}{l}\text { yòu1 } \\
\text { (a1) }\end{array}$ & $\begin{array}{l}\text { yòu1 } \\
\text { (a2) }\end{array}$ & $\begin{array}{l}\text { yòu1 } \\
\text { (b1) }\end{array}$ & $\begin{array}{l}\text { yòu1 } \\
\text { (b2) }\end{array}$ & $\begin{array}{l}\text { yòu } 1 \\
\text { (c) }\end{array}$ & $\begin{array}{l}\text { yòu2 } \\
\text { (a) }\end{array}$ & $\begin{array}{c}\text { yòu2 } \\
\text { (b) }\end{array}$ & $\begin{array}{c}\text { yòu3 } \\
\text { (a) }\end{array}$ & $\begin{array}{c}\text { yòu3 } \\
\text { (b) }\end{array}$ \\
\hline The frequency of errors & 3 & 2 & 6 & 4 & 5 & 7 & 1 & 8 & 9 \\
\hline The frequency of occurrence & 1 & 4 & 2 & 3 & 8 & 7 & 6 & 5 & 9 \\
\hline Accumulated score & 4 & 6 & 8 & 7 & 13 & 14 & 7 & 13 & 18 \\
\hline Intra-sequencing & 1 & 2 & 4 & 3 & 5 & 6 & 3 & 5 & 7 \\
\hline
\end{tabular}

In table 5.2, the statistical sequence of "yòu" is sequenced as follows:

1. yòu $1(\mathrm{a} 1)$

2. yòu $1(\mathrm{a} 2)$

3. yòu $1(\mathrm{~b} 2)$ and yòu $2(\mathrm{~b})$

4. yòu $1(\mathrm{~b} 1)$

5. $\quad$ yòu 1 (c) and yòu $3(a)$

6. yòu $2(a)$

7. yòu $3(b)$

The suggestion for a pedagogical grammar for "zài" and "yòu"

After collating the two results and in accordance with the statistical data on the frequency of appearance and error, the researcher presents these internal sequences of "zài" and "yòu" for consideration in order to suggest the following pedagogical sequence for "zài" and "yòu" for Thai university students (Figures 5.1 and 5.2):

Figure 5.1: The pedagogical sequence for "zài" The first teaching-------------------the latest teaching

\begin{tabular}{|c|c|c|c|c|c|c|c|}
\hline $\begin{array}{l}\text { zài1 } \\
\text { (a1) }\end{array}$ & $\begin{array}{l}\text { zài1 } \\
\text { (b) }\end{array}$ & $\begin{array}{l}\text { zài1 } \\
\text { (a2) }\end{array}$ & $\begin{array}{l}\text { zài1 } \\
\text { (a3) } \\
\text { (a2) }\end{array}$ & zài3 & $\begin{array}{l}\text { zài1 } \\
\text { (a4) }\end{array}$ & $\begin{array}{l}\text { zài2 } \\
\text { (a) } \\
\text { zài2 } \\
\text { (b) }\end{array}$ & $\begin{array}{l}\text { zài1 } \\
\text { (c) }\end{array}$ \\
\hline
\end{tabular}

Figure 5.2: The pedagogical sequence for "yòu"

The first teaching--------------------the latest teaching

\begin{tabular}{|c|c|c|c|c|c|c|}
\hline $\begin{array}{l}\text { yòu1 } \\
\text { (a1) }\end{array}$ & $\begin{array}{l}\text { yòu1 } \\
\text { (a2) }\end{array}$ & $\begin{array}{l}\text { yòu1 } \\
\text { (b2) } \\
\text { yòu2 } \\
\text { (b) }\end{array}$ & $\begin{array}{l}\text { yòu1 } \\
\text { (b1) }\end{array}$ & $\begin{array}{l}\text { yòu1 } \\
\text { (c) } \\
\text { yòu3 } \\
\text { (a) }\end{array}$ & $\begin{array}{l}\text { yòu2 } \\
\text { (a) }\end{array}$ & $\begin{array}{l}\text { yòu3 } \\
\text { (b) }\end{array}$ \\
\hline
\end{tabular}


Figure 5.1 and Figure 5.2 show the pedagogical sequence for "zài" and "yòu" which have been deduced from the statistical sequence of "zài" and "yòu" (see table 5.1 and 5.2). The statistical sequence of "zài" and "yòu" will not be applied directly to a pedagogical grammar for "zài" and "yòu" for Thai university students. In terms of pedagogical approaches, although an appropriate sequence for the learning of the adverbial "zài" and "yòu" in Mandarin Chinese should be according to the frequency of occurrence and the frequency of errors, we should consider differences across languages and provide a more customized way of teaching the adverb "zài" and "yòu" to Thai students. Odlin (1989) indicates that similarities and differences between languages can influence grammar acquisition and these may be not only negative influences but also positive influences. For example, according to the hypothesis that the greater the distance between semantics structures, the more difficult the structures are for learners (Teng, 2005), it is recommended that when teachers are introducing the "zài", they should start from the "zài1(a1)" and it should be introduced together with "yòu1(a1)", which are the basic meanings that learners of Mandarin Chinese whose mother tongue is Thai are more familiar with, because Thai students can compare them with the Thai /Ik/. This should be followed by simple rules, such as; "zài" suggests an action that has not yet happened but "yòu" suggests an action by a more determined speaker or an action that has already happened. It should be noted that in teaching other adverbs or any grammatical words concerned with these categories of "zài" and "yòu" one must be plan to teach at the next stage words such as the negation adverb "bù(不)" . "bù" used before or after "zài1" is dissimilar and it depends on different category of "zàil". It is always used before "zài1(a1)" to indicate that the same action or situation will not occur again and it is always used after "zài1(a3)" to indicate that the same action or situation will not occur again in conditional or suppositional clauses etc.

Secondly, it is recommended that teachers should first teach grammar points that are used more frequently and employ more simple sentence structures that are familiar to most students. Thus, it is suggested that "zài1(b)" which is use before a verb to express the sequencing of a situation is used more frequently and with less difficulty than the other categories of "zai", except"zài1(a1)" , and it can also has a formation like "xian ( 先 ) ... zài” , “...le ( 了 ) ... zài”" etc. Thus students will feel some grammar points are easy when shown some formation to remember.

Lastly, other categories of "zài" and "yòu" can have a sequencing teaching according to figure 5.1 and 5.2 on the hypothesis that students should be first taught grammar points which are frequently used, have a lower degree of structural and semantic complexity and are more familiar to learners. Students should be taught grammar points that are less frequently used, have a higher degree of structural and semantic complexity later. Anyway, the guidelines above dictate a pattern of sequencing to a large degree among certain blocks of pattern, yet they allow for considerable flexibility.

Due to the limitations of time and space, the scope of the study has been limited to only the semantic functions as well as the grammatical structure of "zài" and "yòu". As for the other uses of "zài" and "yòu" with any grammatical word, such as with the aspect "了 le" etc, these have not been included in the research scope of the study. Consequently, the research conducted by this study does not show a comprehensive use of "zài" and "yòu". However, at least this paper can be of help in understanding how to determine the sequence of "zài" and "yòu" so that it is more than just a matter of arbitrariness or a common sense decision. The presentation of grammatical structures should be learner-oriented; they should be designed specifically for the learners, grammar should be clearly explained, the simpler the grammar content the better, technical linguistic jargon should be avoided and simple and frequently-spoken language used to explain and also ensure that the grammatical point can achieve $100 \%$ of the learning goal in the last stage. Even though what is suggested in this paper may not seem to be well rooted, it is hoped that the issues raised in this paper will have shown how the Chinese grammar sequence is determined and that decisions are attributable to more than just common sense.

\section{ACKNOWLEDGEMENTS}

This study is funded by Grant for Development of New Faculty Staff of Chulalongkorn University. 


\section{AUTHOR INFORMATION}

Dr. Sasarux Petcherdchoo is currently a Chinese instructor in the Department of Eastern Languages at Chulalongkorn University, in Bangkok, Thailand. After finishing the bachelor and the master of Arts in Chinese from Chulalongkorn University, she received a scholarship from China Scholarship Council (CSC) to pursue her doctoral degree in Linguistic and Applied Linguistics at the Nanjing Normal University, P.R.China from 20012004. Her special interest is on Modern Chinese, focusing on teaching Chinese as a second language.

\section{REFERENCES}

1. Krashen S. 1998. Second Language Acquisition and Second Language Learning. Englewood Cliffs, New Jersey: Prentice-Hall International.

2. Odlin, Terence (ed.). 1994. Perspectives on Pedagogical Grammar, Cambridge: Cambridge University Press.

3. Paisarn Sukjairungwattana. 2007. A comparative Study of adverbs "zài" and "yòu" in Mandarin Chinese and /i:k/ in Thai, Master Degree in Chinese as a Foreign Language, Faculty of Arts, Chulalongkorn university.

4. Pensuda Chowvanich. 2002. Common errors in the use of the Chinese language by Chulalongkorn University Arts students in the academic years 2000 and 2001, Master Degree in Chinese, Faculty of Arts, Chulalongkorn university.

5. Teng, Shou-hsin. 1997. Towards a pedagogical grammar of Chinese, Journal of Chinese Language Teachers Association 32. 2. 29-40.

$6 . \quad$----od 1998. Sequencing of Structures in a Pedagogical Grammar. Journal of Chinese Language Teachers Association 33. 2. 41-52.

$7 . \quad$-- 1999. Acquisition of LE in L2 Chinese. World Chinese Teaching. 56-64.

8. - --- 2006. Contrastive Analysis and Instruction of Grammar, in Chinese Language Instructional Materials and Pedagogy, pp.175-187. Beijing: Beijing Language and Culture University Press.

9. Westnet, Paul. 1994. Rules and pedagogical grammar, in Perspectives on Pedagogical Grammar, Terence Odlin(ed.), pp.72-96. Cambridge: Cambridge University Press.

10. 邓守信(Teng, Shou-hsin). 2005. 现代汉语语法论文集. 台北 : 文鹤出版社.

11. 吕叔湘 (Lü Shūxiāng). 1999. 现代汉语八百词. 北京:商务印书馆.

12. 刘月华等(Liú Yuèhuá). 2001. 实用现代汉语语法 (增订本). 北京: 商务印书馆.

13. 卢福波 (Lú Fúbō). 2003. 对外汉语教学实用语法. 北京: 北京语言学院.

14. 赵元任(Zhào Yuánrèn). 1968. 语言问题. 台北：台湾商务. 


\section{NOTES}

